\title{
DAILY ACTIVITY PATTERNS OF WOLVES IN OPEN HABITATS IN THE DAURIA ECOREGION, RUSSIA
}

\author{
Anastasia V. Kirilyuk ${ }^{1,2, *} \mathbb{D}$, Vadim E. Kirilyuk ${ }^{1,3}{ }^{\mathbb{D}}$, Alexander N. Minaev ${ }^{4}$ \\ ${ }^{1}$ Daursky State Nature Biosphere Reserve, Russia \\ ${ }^{2}$ Northeast Forestry University, China \\ *e-mail:akiriliuk@bk.ru \\ ${ }^{3}$ Institute of Natural Resources, Ecology and Cryology of the Siberian Branch of the RAS, Russia \\ ${ }^{4} A . N$. Severtsov Institute of Ecology and Evolution of the RAS, Russia
}

Received: 06.04.2021. Revised: 15.10.2021. Accepted: 18.10.2021.

\begin{abstract}
There are very little data about daily activity patterns of Canis lupus (hereinafter - wolf) living in open arid habitats with low human density in Dauria. Therefore we have studied the influence of human activity, reproduction and weather conditions on daily patterns and duration of the activity of 17 GPS-collared wolves in the Daursky State Nature Biosphere Reserve, Russia, from 2015 to 2020. GPS-collars were equipped with acceleration sensors. Wolves were active $44 \%( \pm 0.02 S E)$ of the day and traveled $1.21 \mathrm{~km} / \mathrm{h}( \pm 0.10 \mathrm{SE})$ on average. The mean duration of subsequent activity periods was $7.36 \mathrm{~h}( \pm 1.5 S D)$. The duration of the subsequent, inactivity period was $10.07 \mathrm{~h}( \pm 4.2 S D)$. Travelling speed significantly increased when wolves made extraterritorial forays from their home range to territories of neighbouring packs. The highest activity index corresponds to long-distance dispersing wolves. Weather conditions and human activity did not significantly effect wolves daily activity patterns. Wolves were generally less active and mobile during the cold season. All wolves showed crepuscular movement peaks. Five of the wolves' movement patterns switched to diurnal eight cases when they conducted an extraterritorial foray crossing territories of neighbouring packs. We conclude that wolves' daily activity patterns were mainly shaped by a combination of several factors.
\end{abstract}

Key words: activity index, arid habitats, breeding, Canis lupus, Daursky Biosphere Reserve, dispersing, human activity

\section{Introduction}

Wolf-livestock conflict represents a major wildlife management issue in Asia, where Canis lupus Linnaeus, 1758 (hereinafter - wolf) populations overlap extensively with livestock husbandry. In the south of Zabaikalsky Krai (Russia), this is especially true, as wolves are the most widely distributed large carnivores, and the rural human population relies primarily on livestock for subsistence. In spite of the fact that attacks on livestock were relatively rare, attitudes toward the wolf have been consistently neutral-to-negative in the Zabaikalsky Krai (Kirilyuk \& $\mathrm{Ke}, 2020)$. But since human-wolf conflicts have a two-way orientation, it is also important to study the wolf behavioural response to human activity.

Studies of wolves have documented several factors that may influence their activity patterns. The time periods, when animals are active during the day and movements are influenced by the social and physiological status of wolves, can vary with age and sex (Jedrzejewski et al., 2001; Theuerkauf et al., 2003a; Eggermann et al., 2009), dominance (Mech, 1999), reproductive (Vilà et al., 1995; Theuerkauf et al., 2003a; Tsunoda et al., 2008) and social affiliation (Mancinelli et al., 2019; Yachmennikova \& Poyarkov, 2011). Besides these intrinsic factors, there are environmental factors that also modify the activity and movements of wolves, including availability and activity of prey species (Messier, 1985, 2011; Theuerkauf, et al., 2003a), as well as weather conditions and human activity (Vilà et al., 1995; Ciucci et al., 1997; Theuerkauf et al., 2003a, 2007; Kusak et al., 2005; Chavez \& Gese, 2006; Kaartinen et al., 2015; Kirilyuk \& Kirilyuk, 2019).

Wolf's behavioural responses towards human activities have been extensively studied and proved to be the most significant in human-modified environments inhabited by wolves (Chapron et al., 2014; Mancinelli et al., 2018). In such cases, wolves might be minimising encounters with humans by being less active during daytime (Vilà et al., 1995; Ciucci et al., 1997; Kusak et al., 2005; Chavez \& Gese, 2006); selecting closed (forests) and semi-open (brushland and marshland) habitats (Vilà et al., 1995; Kusak et al., 2005; Chavez \& Gese, 2006), as well as open vegetation communities during the night (Chavez \& Gese, 2006); establishing home ranges in areas with low human activity and high hiding features (Karlsson et al., 2007; Mancinelli et al., 2018), especially in selection of areas for dens and diurnal retreat areas (Theuerkauf et al., 2003b; Iliopoulos et al., 2014; Karamanlidis et al., 2016); tending to avoid anthropogenic structures (Kaartinen et al., 2015; Kojola et al., 2016). However, both wolves living 
in high-human-density areas and wolves inhabiting low-human-density areas are mostly nocturnal (Scott \& Shackleton, 1982). Wolves historically and currently occupying areas with the vast amounts of open habitats, such as Arctic and steppe regions, are inherently capable of utilising areas with vast open habitat during daylight (Chavez \& Gese, 2006). We assume that the animals living in such open habitats with low human density would change their activity patterns due to some intrinsic factors or weather conditions, rather than the human activity (disturbance) factor. However, we paid special attention to this factor, as well as determining whether it shapes high activities of wolves during this time of the day. Since humans are the only direct threat to wolves among «predators» in the study area, and wolf harvesting is officially allowed in unprotected areas, poaching occurs as well, while Kirilyuk \& Ke (2020) previously found that wolves attacked sheep mostly at night or in the early morning (before 10:00 h).

There is a lack of data on daily activity patterns of wolves living in Central Asia. To obtain information about this subject in the Dauria Region, we tracked wolves by GPS-collars in the Daursky State Nature Biosphere Reserve, Russia. This area represents the southeastern part of the wolf's distribution range in the steppe biome of Central Asia. The aim of our study was to determine how reproduction, dispersal, age, weather conditions and human activity affect the wolf activity.

\section{Study area}

The study area $\left(49.50-50.50^{\circ} \mathrm{N}, 114.20\right.$ $117.20^{\circ} \mathrm{E}$ ) is the Daursky State Nature Biosphere Reserve and its buffer zone are located in the southeast of Zabaikalsky Krai, Russia, on the border with Mongolia (Dornod Aimag) and China (Hulunbuir Province) (Fig. 1). The Daursky State Nature Biosphere Reserve contains a core zone of $841.06 \mathrm{~km}^{2}$ and a buffer zone of $1387.7 \mathrm{~km}^{2}$. The study area also contains the Valley of Dzeren Nature Refuge $\left(2138.38 \mathrm{~km}^{2}\right)$ and the «Tsasucheyskiy Bor» Nature Refuge $\left(579 \mathrm{~km}^{2}\right)$. Since they are under the jurisdiction of the Daursky State Nature Biosphere Reserve administration, hereinafter we use the term «Daursky Biosphere Reserve» to include all the Protected Areas (hereinafter - PAs) (Fig. 1). The Dauria Ecoregion is one of the most extensive and well-preserved expanses of steppes in the world. It has been highlighted as one of the most important ecological regions of the planet (WWF Global 200 initiative), and it was recently listed as a World Nat- ural Heritage Site (within the «Landscapes of Dauria»). The study area contains the main ecosystems of the Dauria Ecoregion (see Fig. 1).

The average altitude of the study area is 600 $800 \mathrm{~m}$ a.s.l. On most sites, the landscape comprises rolling plains with hills, ridges and uplands. The climate is ultra-continental, with hot summers and dry, cold winters (Kirilyuk et al., 2014). The mean annual temperature is $-0.6^{\circ} \mathrm{C}$. The warmest month is July (the average monthly temperature is $20.7^{\circ} \mathrm{C}$; the absolute maximum is $+42.4^{\circ} \mathrm{C}$, according to the Solovyevsk settlement weather station, $49.9017^{\circ} \mathrm{N}$, $115.7135^{\circ} \mathrm{E}$ ). The coldest month is January (the average monthly temperature is $-23.1^{\circ} \mathrm{C}$; absolute minimum is $-48.5^{\circ} \mathrm{C}$ ). The annual precipitation varies in the range of 150-350 $\mathrm{mm}$ (on average, 290 $\mathrm{mm})$. About $80 \%$ of the precipitation falls in summer (June - August). The winters are frosty, windless, with little snow. A stable snow cover is established in November - December, but in some years, no snow cover is being formed at all. Snow usually disappears in March, mostly due to evaporation (Kirilyuk et al., 2014). In 2016-2020, the maximum depth of the snow cover was less than $17 \mathrm{~cm}$ (in average, $8.1 \mathrm{~cm}$ ). The snow depth was negligible for our analysis (Musiani et al., 1998).

According to the zoogeographical zoning, the study area belongs to the steppe zone of the Central Asian Desert-Steppe Ecoregion. The wolf is the most abundant carnivore species in the study area (Kirilyuk et al., 2014). Procapra gutturosa Pallas, 1777, Capreolus pygargus Pallas, 1771, Lepus tolai Pallas, 1778, and Marmota sibirica Radde, 1862 represent the main wild prey available to wolves. In the study area, the wild prey density is relatively high due to the habitat suitability and presence of well-managed reserves. Thus, the wild ungulate biomass index per $1000 \mathrm{~km}^{2}$ was 5664 in 20152016 (Kirilyuk et al., 2019). The Daursky Biosphere Reserve supports approximately six wolf packs. Five of them had been studied previously, with a mean size of the home range, $832 \pm 79.05$ $\mathrm{km}^{2}$ at $100 \%$ minimum convex polygons (Kirilyuk et al., 2019). According to the results of the winter route census conducted in 2015-2020 by the Daursky Biosphere Reserve's staff, the wolf density ranged from 2.6 to 0.1 per $100 \mathrm{~km}^{2}$; the lowest wolf density was reported in 2017-2019, when the number of wolves had decreased due to the mange (Sarcoptes scabiei Linnaeus, 1758) pandemic. At least five wolf packs are transboundary that means that their home ranges cover areas in both Russia and in Mongolia. 


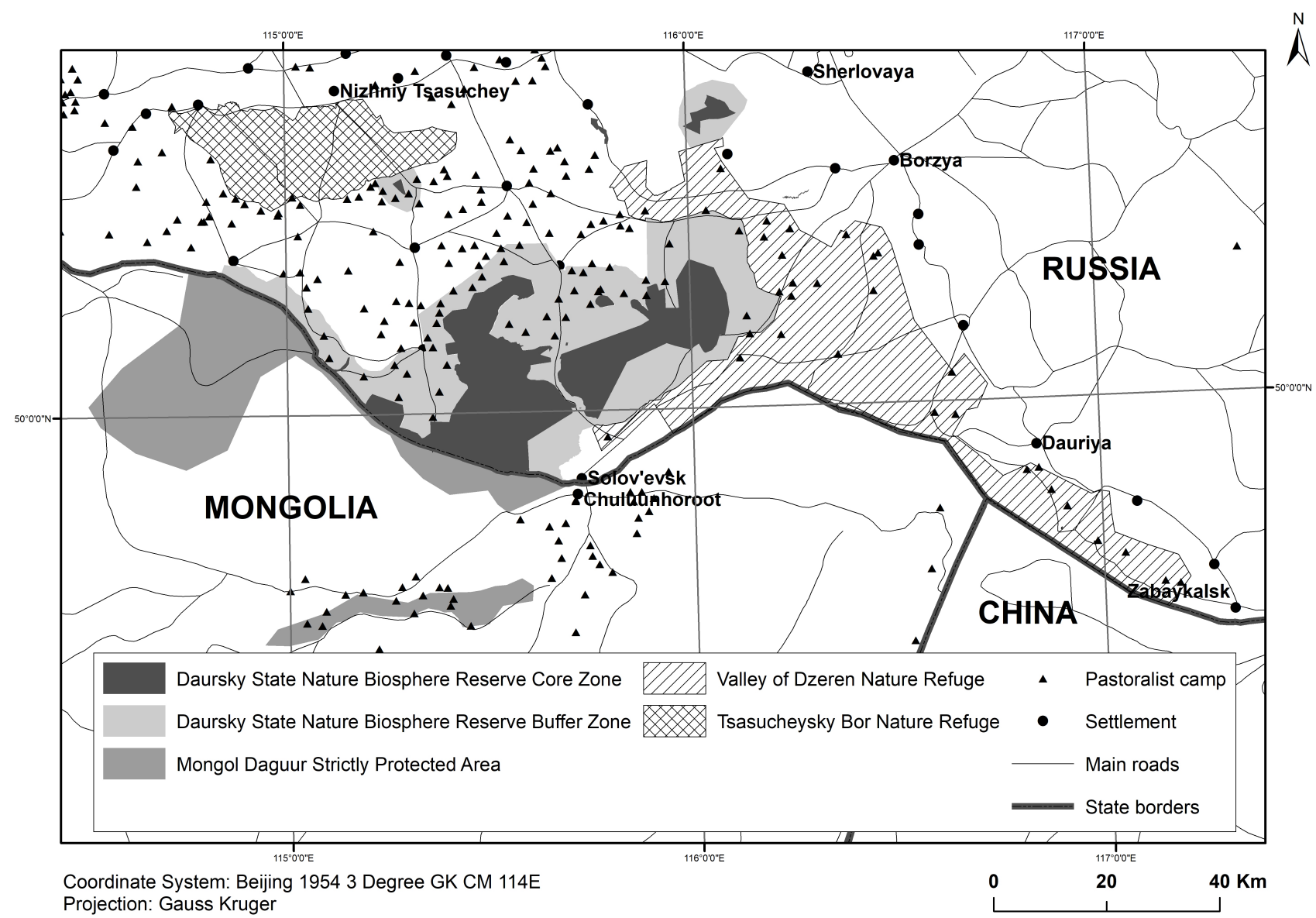

Fig. 1. Study area located in the southeastern part of the Zabaikalsky Krai, Russia, representing the northeastern part of the wolf distribution range in the steppe biome. The map does not include the buffer zone of «Mongol Daguur» Strictly Protected Area, Mongolia; as there is no nature protection regime, it is simply a zone of co-operation. Only the main roads are shown. However, the used current steppe roads were also included in the analysis.

In the study area, human activity is concentrated only in the buffer zone of the Daursky Biosphere Reserve, and in the mentioned-above nature refuges. In settlements and pastoralist camps, it does not exceed $2 \mathrm{~km}$ around them, as well as along the roads. The study area is an important agricultural region where livestock raising prevails. In the study area, nomadic pastoralists raise domestic animals (Bos taurus Linnaeus, 1758; Ovis aries Linnaeus, 1758; Capra hircus Linnaeus, 1758; Equus ferus caballus Linnaeus, 1758, and Sus scrofa domesticus Linnaeus, 1758). Hay producers and hunters are active seasonally. The hunting season on wolves runs from 15 September to 28 February, being established by the Resolution of the Governor of the Zabaikalsky Krai dated on 22.06.2015, №63. Hunting is strictly prohibited in Protected Areas and their buffer zones. There is a small activity of tourists, largely related to summer activities, particularly in the Daursky Biosphere Reserve.

The human density is about 0.05 inhabitants/ $\mathrm{km}^{2}$ in the Daursky Biosphere Reserve, representing mostly pastoral camps' inhabitants, $0.56,1.65$ and 5.49 inhabitants $/ \mathrm{km}^{2}$ in the surrounding area (Dor- nod Aimag (Mongolia), Ononskiy district, Borzinskiy district (both - Russia), respectively), representing mostly settlements' residents. Pastoral camps are unevenly distributed. Their maximum density is 0.02 camps $/ \mathrm{km}^{2}$ (minimal: $0.001 \mathrm{camps} / \mathrm{km}^{2}$ ), and approximately the same within the Daursky Biosphere Reserve and its surrounding area. The density of the currently used roads is about $0.28 \mathrm{~km} / \mathrm{km}^{2}$ in the Daursky Biosphere Reserve, with about $80 \mathrm{~km}$ of stabilised roads $\left(0.018 \mathrm{~km} / \mathrm{km}^{2}\right)$. The overall roads' density of the surrounding area is the same. Traffic in the study area consists mostly of cars, trucks, tractors, and motorcycles. Pastorals (or shepherds) mainly move by vehicles, on horses or on foot, and usually remain on trails or steppe roads.

\section{Field procedures}

We used remote tracking to study the wolves' activity patterns. We captured and tracked 20 wolves from 2015 to 2020. Among them three wolves (two females and one male) died in the process of capture. According to visual observations, one female was sick; more than $70 \%$ of the skin was affected by ectoparasites (i.e. Sarcoptes scabiei Linnaeus, 1758). 
The male died because of cardiorrhesis caused by the stress. The cause of the death of the second female is unknown. We immobilised these animals from a jeep, following a chase method described for Asiatic wild equids by Walzer et al. (2006). Wolves were anesthetised with xylazine $(2 \%)$ at a dose of approximately $0.07-0.12 \mathrm{ml} / \mathrm{kg}$ (Kirilyuk et al., 2019). The study animals were aged by tooth wear and by body size (Gipson et al., 2000), and examined to determine their physical condition. Wolves were divided into three age categories: pups (up to 12 months old), yearlings (12-24 months old), and adults (more than 24 months old). We fitted the wolves with GPS+GSM custommade collars (500-550 g; Kirilyuk et al., 2019), and programmed the collars to collect date, time, and a GPS-location (latitude and longitude; WGS 84) every hour, activity data every $10 \mathrm{~min}$, and to transmit data daily through the Global System for Mobile Communications (GSM). In the absence of a GSM net, the collar stored data in internal memory and later transmitted them when GSM appeared. We used ET-318 (GlobalSat) and M8Q (Ublox) GPS modules; SIM800 and SIM900 (Simcom) GSM modules.

The collars had acceleration sensors (MMA8652FC, Freescale Semiconductor). If an animal was moving, we got larger values of accelerations compared to those obtained if the animal was at rest. Acceleration values in three axes were read out about 30 times within $30 \mathrm{~s}$. To make an «active» / «inactive» decision, the absolute value (modulus) of the difference between the previous and next values along three axes was summarised. If a collar was motionless, then the sensor gave out the value of $g$ (gravity), and the modulus of the difference is about zero. The collars of lying animals moved little, and the modulus of the difference was small, while for walking and running animals, it increased. The threshold value, upon overcoming which the animal was considered active, was determined empirically, by comparing visual observations and activity records during experiments. We defined the length of an active (or inactive) period as an uninterrupted block of readings during which the animal was active (or inactive). Short activity changes between two readings (e.g. scratching, shaking its head or rising for a moment while resting, lasting less than $30 \mathrm{~s})$ were not detected with this method and were not defined as «active». The activity index is calculated as the sum of «active» readings $(1=$ active $)$ divided by the quantity of all readings $(0=$ inactive and $1=$ active) during a considered interval.

We projected wolves' locations and analysed the data in NextGIS QGIS 17.7.0, by determining that inaccuracy of GPS-position was negligible at the scale of our analysis (inaccuracy of the GPS-position was $10 \mathrm{~m}, 2 \mathrm{D}$ RMS; www.globalsat.ru). The mean GPS-success rate of wolves was $60 \%$. For all calculations, we excluded days in which there were no successful GPS-fixes. Periods of no successful GPSfixes were unevenly distributed, and these periods were most often during non-directional movement patterns (including sleeping periods). We also excluded GPS-fixes from the first day, to eliminate data mistakes caused by the stress factor after anesthetic.

Wolf packs are not fixed units, and wolves show significant variation in daily activity patterns among individuals in the same pack (Theuerkauf et al., 2003a). In our study, we decided to use the individual wolf rather than the wolf pack as the sample unit because we did not collect enough data on wolves of the same pack at the same tracking period to calculate correlation coefficients of daily activity within or among packs.

Capturing wolves was carried out by tracking along paw print tracks in the fresh snow, and/or by observing landscapes with binoculars during daylight hours. In both cases, the more experienced, cautious, or strong wolves were able to avoid capture. Such behaviour was documented (Kochetkov, 2007), when adults more successfully avoided humans in comparison with younger animals. Therefore, our sample, which has a predominance of males $(65 \%)$ and pups (24\%), probably, does not reflect the wolf population structure in the study area (Kochetkov, 2007).

We defined two categories of wolves' social status: (1) pack members and (2) floaters (dispersers). The pack members category was established by assessing whether the radio-collared wolves were living with other pack members, or staying near the pack's social centre (dens, rendezvous sites). With this objective, besides inspecting the movement path of obtained GPS-location data, we also tried to observe the wolves actively, by checking the tracks in the snow. We carried out 54 tracking sessions at rendezvous sites and seven at dens sites, including the use of camera traps. In addition, we annually conducted pastoral surveys. We collected data from their observations on wolves. We considered a wolf to be dispersed from its natal home range once it moved outside a natal home range area boundary to the place where it reproduces or would have reproduced, if it had survived or found a mate (Greenwood, 1980) and do not show site fidelity (Kojola et al., 2006; Blanco \& Cortés, 2007). Before leaving a natal home range, some wolves made pre-dispersal forays or spent time in the periphery of their natal 
home range (Messier, 1985; Blanco \& Cortés, 2007). If we could not exactly define the status of a wolf, then we used the term «unconfirmed».

We used the method of $100 \%$ minimum convex polygon (MCP) (White \& Garrot, 1990) to calculate the boundaries of home range areas. We defined a wolf pack to be under protection within a Protected Area, if more than $60 \%$ of its core area was within a Protected Area. For calculating the home range core area boundaries, we used the method of 50\% fixed kernel (Worton, 1989). As three wolves (M1, F6 and F7) resettled and established new packs or joined already-existing ones, to analyse the activity index of wolves living/being in Protected Areas and unprotected areas, and during the daylight in the hunting season, we also used data of the pre-dispersing, dispersing and post-dispersing period of M1 and F6, and data on F7 pre-dispersing period (there were no reliable data on the activity of the wolf after 05.01.2019). We excluded data of extraterritorial forays in conducting this analysis, as wolves' extraterritorial foray activity was analysed separately.

All activity readings and GPS-fixes were categorised in three seasons, and were considered as conditional seasons of the year: breeding season (April - June), warm season (July - October, pups raising, dispersing), and cold season (November - March, including wintering, mating season, pre-dispersing forays). Data on sunrise and sunset time, day and night length were obtained from the online database of timewek.ru. We have used the approach by Chavez \& Gese (2006) in northwestern Minnesota, USA, and we classified the four periods of the day as follows: dawn ( $1 \mathrm{~h}$ before to 2 $\mathrm{h}$ after sunrise), day ( $2 \mathrm{~h}$ after sunrise to $1 \mathrm{~h}$ before sunset), dusk ( $1 \mathrm{~h}$ before to $2 \mathrm{~h}$ after sunset), and night ( $2 \mathrm{~h}$ after sunset to $1 \mathrm{~h}$ before sunrise). Dawn and dusk periods ( $3 \mathrm{~h}$ each) were defined daily for local sunrise and sunset times, and the length of daylight and night periods varied accordingly.

Data on the weather (day mean temperature, ${ }^{\circ} \mathrm{C}$; precipitation intensity, $\mathrm{mm}$; wind force, $\mathrm{m} / \mathrm{s}$ ) were obtained from the weather station of the Solovyevsk settlement under a direct agreement with the Daursky Biosphere Reserve. The weather station location is the nearest to the centre of all wolves' home ranges and at an average distance of $51.5 \mathrm{~km}(\mathrm{n}=15)$ to them. As the study area is rolling plains and the correlation of weather data between the nearest weather station of the Borzya settlement (80 km away from the Solovyevsk settlement) and the station of the Solovyevsk settlement is high (e.g. for air temperature, Pearson's $r$ test: $r=0.95$; for precipitation, Pear- son's $r$ test: $r=0.66$ ), we determined the inaccuracy of the weather data to be negligible at the scale of our analysis. We separately determined data on the weather for each wolf during each 24-h tracking session, while we excluded data on F6 and F7 during dispersing and post-dispersing periods. During dispersing and post-dispersing periods, location data of these two females could not be used in the analysis, as their locations were too far away from the weather station of the Solovyevsk settlement (more than 100 $\mathrm{km}$ ), and we were not able to obtain data from other, nearer, weather stations. We examined wolves' activity patterns on days with snowfall and right after a snowfall. We used data on days when the snow cover was formed (more than $0.1 \mathrm{~cm}$ ). Data on the snow depth were obtained from the annual animal winter track census conducted by the Daursky Biosphere Reserve and from the weather station of the Solovyevsk settlement.

We calculated two metrics to quantify the wolf's movement behaviour. The first one is the minimum distance traveled daily by summing the distances between all successive GPS-locations received within each 24-h period (midnight - midnight). The second one is the minimum travel speed (hereinafter - travel speed), $\mathrm{km} / \mathrm{h}$ and $\mathrm{km} /$ day, considered as the minimum distance divided by the time, which was then averaged (Kirilyuk et al., 2020).

Human density was calculated according to official statistics on the number of people in villages (for cases when it was within the home range boundaries of a pack), and, according to surveys on the number of people in pastoral camps, annually conducted by the Daursky Biosphere Reserve. For analysis, we used data on the road density only for those roads that passed through the territories of wolves. To analyse anthropogenic factors affecting the wolves' activity index and travel speed $(\mathrm{km} / \mathrm{h})$, we used data on 15 wolves (17 territories, see above) for whom we could calculate $100 \% \mathrm{MCP}$ home range.

We used the t-test for paired samples, analysis of variance (ANOVA, for large datasets) and Pearson's $r$ test for analysis of activity distribution, correlations, and significance of differences in activity patterns. We generated linear models to detect how the length of active and inactive periods, weather conditions and disturbance factors affected activity patterns and travel speed of wolves. We performed all statistical tests with SPSS Statistics 26 (IBM Corp., Armonk, NY) and R 3.4.2 (R Core Team, 2020). All graphics were performed using Microsoft Office Excel 2019. All results were assumed significant at $p<0.05$. Means presented as $\pm S D$ (or $\pm S E$ ). 


\section{Results}

From 11.03.2015 to 27.01.2020, 402750 (including « 0 » and «1» readings, see Material and Methods; mean: $23691 \pm 18$ 534.5 SD) activity readings and 57252 (mean: $3368 \pm 2588 S D$ ) locations were recorded for 17 tracked wolves (Table 1). There was no significant difference in index activity between female and male wolves (t-test for paired samples: $t=0.104, d f=15, p=0.919$, Table 2), so the data were pooled. We also pooled and analysed together pre-dispersal, dispersal and/ or post-dispersal activity index of floaters, as it was not significantly different (ANOVA: $F_{2,7}=0.237$, $p=0.795)$. Wolves were active $44 \%$ of the day on average and travelled $1.26 \pm 0.06 \mathrm{~km} / \mathrm{h}$ (Table 2). The longest activity period was $10.8 \mathrm{~h}$ (mean $\pm \mathrm{SD}$ : $7.36 \pm 1.49 \mathrm{~h}$ ) and the longest period of inactivity was $18 \mathrm{~h}($ mean $\pm \mathrm{SD}: 10.07 \pm 4.2 \mathrm{~h}$; Table 1$)$. There were no significant differences of the longest activity and inactivity period between female/male (t-test for paired samples: $t=0.207, d f=15, p=0.839$, $t=1.234, d f=15, p=0.236$, respectively) and dispersing wolves /pack members (t-test for paired samples: $t=-0.843, d f=9, p=0.421, t=0.742$, $d f=9, p=0.477$, respectively).

The highest activity index was among dispersing wolves, rather than among pack members (t-test for paired samples: $t=-4.343, d f=9, p=0.002$ ), while travel speed $(\mathrm{km} / \mathrm{h})$ did not significantly differ $(\mathrm{t}$ test for paired samples: $t=0.912, d f=9, p=0.386$ ). The activity index did not differ between the age categories of the wolves (ANOVA: $F_{214}=3.018$, $p=0.081$; Table 1, Table 2), neither the duration of active (ANOVA: $F_{214}=0.044, p=0.957$ ) and inactive period (ANOVA: $F_{2,14}=1.719, p=0.215$ ), or travel speed $\left(\mathrm{km} / \mathrm{h}\right.$, ANOVA: $F_{2.14}=0.463, p$ $=0.639 ; \mathrm{km} / \mathrm{d}$, ANOVA: $\left.F_{2,14}=0.003, p=0.997\right)$. But we found a high correlation between travel speed $(\mathrm{km} / \mathrm{h})$ and daily activity index (Pearson's $r$ test: $r=0.876, p=0.000$; Fig. 2).

Table 1. Age, status, activity readings, duration of maximum active/inactivity period of collared wolves in the Daursky State Nature Biosphere Reserve, Russia, 2015-2020

\begin{tabular}{|c|c|c|c|c|c|c|c|c|}
\hline № & Wolf & Sex & $\begin{array}{l}\text { Age, } \\
\text { year }\end{array}$ & Tracking period & Social status & $\begin{array}{l}\text { Activity } \\
\text { readings }\end{array}$ & $\begin{array}{c}\text { Maximum } \\
\text { active period, } \mathrm{h}\end{array}$ & $\begin{array}{c}\text { Maximum } \\
\text { inactive period, } \mathrm{h}\end{array}$ \\
\hline 1 & F1 (Hamary) & Female & $3-4$ & 16.05.2015-28.06.2016 & $\begin{array}{l}\text { Pack member, } \\
\text { breeding female }\end{array}$ & 43776 & 8.0 & 9.3 \\
\hline 2 & M1 (Pilniy) & Male & $0-1$ & $\begin{array}{l}\text { Entire period } \\
\text { Pre-dispersing: } 11.03 .2015-27.08 .2015 \\
\text { Dispersing: } 28.08 .2015-13.10 .2015 \\
\text { Post-dispersing: } 14.10 .2015-24.02 .2016\end{array}$ & Floater & $\begin{array}{c}39640 \\
22752 \\
6192 \\
10694\end{array}$ & $\begin{array}{l}8.8 \\
6.7 \\
7.6 \\
8.8\end{array}$ & $\begin{array}{l}8.5 \\
8.5 \\
6.3 \\
7.2\end{array}$ \\
\hline 3 & M2(Bodriy) & Male & $>5$ & $27.10 .2015-14.10 .2016$ & Pack member & 37584 & 7.7 & 9.6 \\
\hline 4 & M3 (Hodan) & Male & $2-3$ & $20.01 .2016-02.09 .2016$ & Pack member & 19296 & 5.3 & 15.2 \\
\hline 5 & M4 (Brodyaga) & Male & $0-1$ & 11.03.2016-19.06.2017 & Pack member & 25962 & 9.3 & 12.3 \\
\hline 6 & F2 (Zuna) & Female & $1-2$ & 13.12.2016-12.02.2017 & Pack member & 7056 & 6.5 & 17.8 \\
\hline 7 & F3 (Sonya) & Female & $1-2$ & $25.12 .2016-04.03 .2017$ & Unconfirmed & 6480 & 6.5 & 18.0 \\
\hline 8 & M5 (Arshan) & Male & $1-2$ & $11.12 .2016-05.10 .2017$ & Unconfirmed & 31824 & 7.16 & 8.0 \\
\hline 9 & M6 (Upriamiy) & Male & $3-4$ & 23.12 .201621 .01 .2017 & Pack member & 4176 & 6.3 & 8.0 \\
\hline 10 & M7 (Hozain) & Male & $1-2$ & $\begin{array}{l}\text { Entire period } \\
\text { Pre-dispersing: 04.02.2017-13.02.2017 } \\
\text { Dispersing: 13.02.2017-04.03.2017 }\end{array}$ & Floater & $\begin{array}{l}2880 \\
1338 \\
1542 \\
\end{array}$ & $\begin{array}{l}5.7 \\
4.5 \\
5.7\end{array}$ & $\begin{array}{c}13.6 \\
4.8 \\
13.6\end{array}$ \\
\hline 11 & M9 (Materiy) & Male & $2-3$ & $14.02 .2017-21.09 .2017$ & Unconfirmed & 25488 & 6.8 & 7.8 \\
\hline 12 & F4 (Havirga) & Female & $2-3$ & $18.11 .2017-17.12 .2018$ & $\begin{array}{l}\text { Pack member, } \\
\text { breeding female }\end{array}$ & 36576 & 6.8 & 8.5 \\
\hline 13 & M10 (Bain-Han) & Male & $2-3$ & $30.12 .2017-17.03 .2019$ & Unconfirmed & 61920 & 10.8 & 7.3 \\
\hline 14 & M11 (Zun) & Male & $0-1$ & 09.03.2018-29.03.2018 & Unconfirmed & 2880 & 6.8 & 3.2 \\
\hline 15 & F6 (Zalezh) & Female & $1-2$ & $\begin{array}{l}\text { Entire period } \\
\text { Pre-dispersing: } 27.10 .2018-15.03 .2019 \\
\text { Dispersing: } 16.03 .2019-11.04 .2019 \\
\text { Post-dispersing: } 12.04 .2019-06.12 .2019\end{array}$ & Floater & $\begin{array}{c}45360 \\
17034 \\
534 \\
27792 \\
\end{array}$ & $\begin{array}{l}9.3 \\
7.7 \\
4.7 \\
9.3\end{array}$ & $\begin{array}{l}4.7 \\
4.7 \\
4.7 \\
3.0\end{array}$ \\
\hline 16 & F7 (Nora)* & Female & $1-2$ & $\begin{array}{l}\text { Entire period } \\
\text { Pre-dispersing: } 27.10 .2018-26.03 .2019 \\
\text { Dispersing: } 27.03 .2019-05.04 .2019 \\
\text { Post-dispersing: } 05.04 .2019-26.06 .2019\end{array}$ & Floater & $\begin{array}{c}7242 \\
7242 \\
- \\
-\end{array}$ & $\begin{array}{l}7.7 \\
7.7 \\
- \\
-\end{array}$ & $\begin{array}{c}12.2 \\
12.2 \\
- \\
-\end{array}$ \\
\hline 17 & M14 (Bulat) & Male & $0-1$ & $01.12 .2019-07.01 .2020$ & Unconfirmed & 4608 & 5.7 & 7.3 \\
\hline
\end{tabular}

Note: * There were no reliable data on the activity of F7 after 05.01.2019. 
Table 2. Activity index, travel speed $(\mathrm{km} / \mathrm{h})$ of collared wolves in the Daursky State Nature Biosphere Reserve, Russia during the day, dusk, night and dawn in breeding, warm and cold seasons

\begin{tabular}{|c|c|c|c|c|c|c|c|c|c|c|}
\hline \multirow[b]{2}{*}{ № } & \multirow{2}{*}{ Wolf Variables } & \multicolumn{4}{|c|}{ Activity index } & \multicolumn{5}{|c|}{ Travel speed, $\mathrm{km} / \mathrm{h}$} \\
\hline & & Entire period & $\begin{array}{l}\text { Breeding } \\
\text { season }\end{array}$ & Warm season & Cold season & Entire period & Daylight & Dusk & Night & Dawn \\
\hline 1 & F1 (Hamary) & $0.35 \pm 0.007$ & $0.25 \pm 0.01$ & $0.43 \pm 0.01$ & $0.37 \pm 0.01$ & $1.17 \pm 0.15$ & $0.41 \pm 0.09$ & $1.33 \pm 0.29$ & $1.90 \pm 0.08$ & $1.08 \pm 0.41$ \\
\hline 2 & M1 (Pilniy) & $0.54 \pm 0.006$ & $0.47 \pm 0.01$ & $0.48 \pm 0.007$ & $0.64 \pm 0.02$ & $1.39 \pm 0.15$ & $0.62 \pm 0.15$ & $1.57 \pm 0.31$ & $1.83 \pm 0.09$ & $2.20 \pm 0.22$ \\
\hline 3 & M3 (Hodan) & $0.36 \pm 0.01$ & $0.39 \pm 0.014$ & $0.39 \pm 0.02$ & $0.32 \pm 0.01$ & $1.01 \pm 0.13$ & $0.45 \pm 0.10$ & $0.82 \pm 0.31$ & $1.70 \pm 0.14$ & $0.81 \pm 0.24$ \\
\hline 4 & M2 (Bodriy) & $0.32 \pm 0.005$ & $0.32 \pm 0.01$ & $0.34 \pm 0.01$ & $0.31 \pm 0,008$ & $1.51 \pm 0.16$ & $0.63 \pm 0.13$ & $1.68 \pm 0.17$ & $2.14 \pm 0.09$ & $2.09 \pm 0.11$ \\
\hline 5 & M4 (Brodyaga) & $0.44 \pm 0.01$ & $0.47 \pm 0.01$ & $0.44 \pm 0.02$ & $0.42 \pm 0.02$ & $1.45 \pm 0.18$ & $0.47 \pm 0.15$ & $1.78 \pm 0.33$ & $2.06 \pm 0.08$ & $2.26 \pm 0.49$ \\
\hline 6 & F2 (Zuna) & $0.42 \pm 0.02$ & - & - & $0.42 \pm 0.02$ & $1.23 \pm 0.11$ & $1.08 \pm 0.26$ & $1.56 \pm 0.05$ & $1.13 \pm 0.07$ & $1.63 \pm 0.35$ \\
\hline 7 & F3 (Sonya) & $0.40 \pm 0.02$ & - & - & $0.40 \pm 0.02$ & $1.48 \pm 0.12$ & $1.37 \pm 0.14$ & $0.86 \pm 0.09$ & $1.85 \pm 0.22$ & $1.30 \pm 0.49$ \\
\hline 8 & M5 (Arshan) & $0.44 \pm 0.006$ & $0.46 \pm 0.01$ & $0.47 \pm 0.01$ & $0.41 \pm 0.02$ & $1.20 \pm 0.14$ & $0.43 \pm 0.09$ & $1.51 \pm 0.26$ & $1.74 \pm 0.13$ & $1.53 \pm 0.19$ \\
\hline 9 & M6 (Upriamiy) & $0.28 \pm 0.03$ & - & - & $0.28 \pm 0.03$ & $1.70 \pm 0.18$ & $1.56 \pm 0.32$ & $2.70 \pm 0.42$ & $1.60 \pm 0.26$ & $1.40 \pm 0.89$ \\
\hline 10 & M7 (Hozain) & $0.47 \pm 0.03$ & - & - & $0.39 \pm 0.03$ & $1.26 \pm 0.09$ & $1.08 \pm 0.18$ & $1.39 \pm 0.36$ & $1.30 \pm 0.10$ & $1.57 \pm 0.17$ \\
\hline 11 & M9 (Materiy) & $0.43 \pm 0.007$ & $0.48 \pm 0.01$ & $0.45 \pm 0.01$ & $0.47 \pm 0.01$ & $1.26 \pm 0.18$ & $0.32 \pm 0.10$ & $1.01 \pm 0.43$ & $2.07 \pm 0.11$ & $1.85 \pm 0.46$ \\
\hline 12 & F4 (Havirga) & $0.39 \pm 0.006$ & $0.41 \pm 0.01$ & $0.41 \pm 0.01$ & $0.38 \pm 0.01$ & $1.14 \pm 0.12$ & $0.49 \pm 0.07$ & $1.11 \pm 0.26$ & $1.68 \pm 0.08$ & $1.48 \pm 0.29$ \\
\hline 13 & M10 (Bain-Han) & $0.52 \pm 0.004$ & $0.51 \pm 0.006$ & $0.53 \pm 0.006$ & $0.53 \pm 0.01$ & $1.49 \pm 0.17$ & $0.56 \pm 0.13$ & $1.64 \pm 0.25$ & $2.22 \pm 0.10$ & $1.91 \pm 0.08$ \\
\hline 14 & M11 (Zun) & $0.55 \pm 0.02$ & - & - & $0.55 \pm 0.02$ & $0.74 \pm 0.13$ & $0.42 \pm 0.12$ & $1.38 \pm 0.36$ & $0.51 \pm 0.09$ & $1.78 \pm 0.60$ \\
\hline 15 & F6 (Zalezh) & $0.58 \pm 0.006$ & $0.56 \pm 0.009$ & $0.60 \pm 0.01$ & $0.58 \pm 0.01$ & $1.04 \pm 0.14$ & $0.30 \pm 0.07$ & $1.15 \pm 0.41$ & $1.54 \pm 0.11$ & $1.65 \pm 0.39$ \\
\hline 16 & F7 (Nora) & $0.48 \pm 0.01$ & - & - & $0.48 \pm 0.01$ & $1.06 \pm 0.12$ & $0.35 \pm 0.11$ & $1.24 \pm 0.15$ & $1.47 \pm 0.04$ & $1.74 \pm 0.15$ \\
\hline 17 & M14 (Bulat) & $0.42 \pm 0.01$ & - & - & $0.42 \pm 0.02$ & $1.27 \pm 0.13$ & $0.90 \pm 0.23$ & $1.92 \pm 0.51$ & $1.22 \pm 0.11$ & $1.89 \pm 0.26$ \\
\hline
\end{tabular}

Note: Activity index and travel speed data are presented as mean \pm SE.

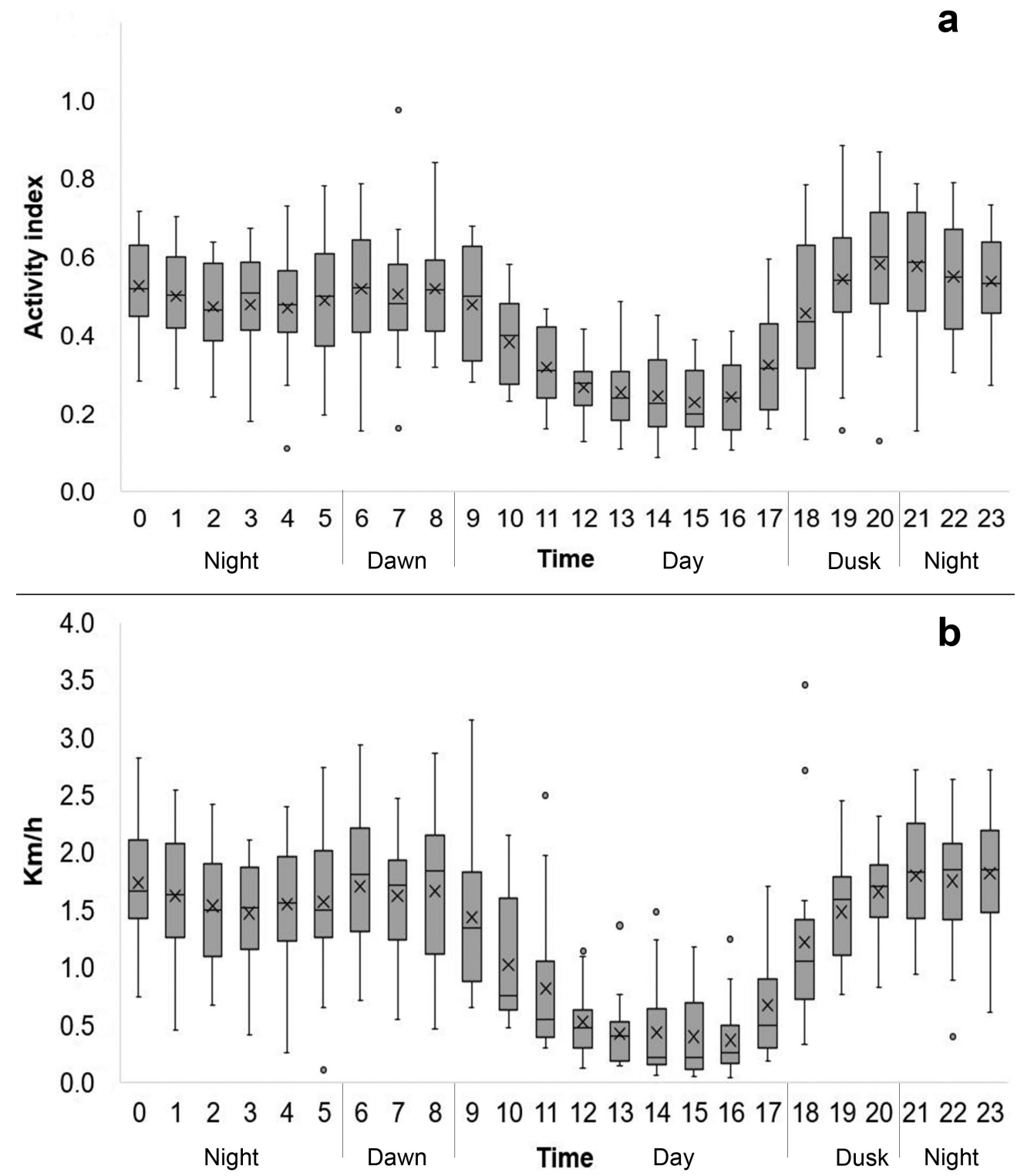

Fig. 2. Daily patterns of mean time active (a) and travel speed (b) of 17 collared wolves for a year-round period in the Dauria Ecoregion, Russia, in 2015-2020. 
Diel activity patterns confirmed the prevalence of noctural activity with peaks at dawn and dusk, which also coincided with the longest subsequent activity period; and troughs in the middle of the day and middle of the night (Table 1; Fig. 2). Peaks of wolf activity followed seasonal changes in time of sunrise and sunset (Fig. 3).

Activity index values for dawn and dusk were not significantly different from indices for the night, but were different from indices for the day (ANOVA: $F_{3,64}=15.613, p=0.000$; Fig. 3). We pooled dawn and dusk indices and analysed them together with data for the night (hereinafter - «night»). Mean year-round wolves' activity indices were significantly higher during the night than during the day: 0.50 vs. 0.27 (t-test for paired samples: $t=-6.722, d f=66, p=0.000)$. The lowest mean night activity index was the same year-round (0.50) and corresponding to the cold season. The highest mean-night activity was during the breeding season (0.62), and it was significantly higher than year-round and cold-season activity (ANOVA: $F_{3,158}=9.417, p=0.000$ ). The highest mean daytime activity was in the cold season (0.27), and was not significantly higher compared to year-round or other two seasons (ANOVA: $F_{3,45}=2.021, p=0.124$; Fig. 3). The mean daytime activity of dispersing wolves was higher than among pack members $(0.33$ vs. 0.22 ; t-test for paired samples: $t=2.730, d f=9$, $p=0.023)$, as well as night activity $(0.57$ vs. 0.45 ; t-test for paired samples: $t=3.209, d f=9$, $p=0.011)$, but daytime $(0.58 \mathrm{~km} / \mathrm{h}$ vs. $0.72 \mathrm{~km} / \mathrm{h})$ and night travel speed $(1.55 \mathrm{~km} / \mathrm{h}$ vs. $1.62 \mathrm{~km} / \mathrm{h})$ was not (t-test for paired samples: $t=-0.544$, $d f=9, p=0.600$ and $t=-0.326, d f=9, p=0.752$, respectively; Table 2).

We detected 45 extraterritorial forays performed by nine wolves, including pre-dispersal movements for three wolves (M1, F6 and F7). Extraterritorial movements lasted on average 38.1 h (ranged: 2-473 h) and almost exclusively during the cold season (67\%). Travel speed was significantly higher when wolves made extraterritorial forays from their natal area to neighbouring pack territories, compared to year-round speed $(2.48 \mathrm{~km} / \mathrm{h}$ vs. $1.21 \mathrm{~km} / \mathrm{h}$; t-test for paired samples: $t=5.492, d f=16, p=0.000)$. Whereas the daytime activity index and the general activity index during forays did not differ from the year-round values (t-test for paired samples: $t=1.814, d f=16, p=0.089$; t-test for paired samples: $t=1.983, d f=16, p=0.065$, respectively), a few wolf movement patterns switched to diurnal when they conducted an extraterritorial foray while crossing neighbouring pack territories. M1 once increased his daytime activity index up to 0.52 (foray lasted $50 \mathrm{~h} ; \mathrm{n}=6$ ), and M10 switched his activity patterns to diurnal four times and increased his daytime activity index up to 0.56 $(26 \mathrm{~h}), 0.81(15 \mathrm{~h}), 0.70(20 \mathrm{~h})$ and $0.63(26 \mathrm{~h}$; $\mathrm{n}=20$ ). Among other wolves that made forays but with shorter lasting times, F4, F6 and F7 raised their daytime activity up to $0.54(7 \mathrm{~h}, \mathrm{n}=3), 0.87$ $(5 \mathrm{~h}, \mathrm{n}=4)$ and $0.67(7 \mathrm{~h}, \mathrm{n}=1)$, respectively. Moreover, F6 and F7 forays were entirely in the daytime. All above-mentioned forays were to the territory of different, neighbouring packs, and most of them were in the winter, except the foray of M1, which was in the spring (May).

Only F1 was definitely observed to breed: we collared F1 when she was with pups in the den. We speculated that F4 was also a breeding female, as while breeding season her movement path was the same as F1, and pastoralists observed her with pups. Breeding females were not less active during the period of denning compared with non-breeding females and males (t-test for paired samples: $t=-1.308, d f=8, p=0.227$; Table 1). But F1 significantly reduced her activity at night (0.33 vs. 0.47 ; t-test for paired samples: $t=6.26$, $d f=13, p=0.000)$ and dawn (0.31 vs. 0.41 ; ttest for paired samples: $t=5.37, d f=4, p=0.012$ ) compared to year-round activity index, while F4 did not, and, in contrast, F4 significantly increased her activity at dusk ( 0.71 vs. 0.49 ; t-test for paired samples: $t=3.44, d f=4, p=0.041$; Table 3). Both females' pups were born in the second half of April. During the breeding period, F1 stayed near the den (up to $1.5 \mathrm{~km}$ ) $28 \%$ of the time, while F4 stayed near the den $21 \%$ of the time (during April, $30 \%$ and $32 \%$, respectively). In the post-denning, warm season, night time activity by female F1 (ttest for paired samples: $t=9.49, d f=12, p=0.000$ ) and F4 (t-test for paired samples: $t=2.77, d f=12$, $p=0.018)$ increased, compared with night activity in breeding season (Table 3). During the rest of the year (warm and cold season), activity of breeding females did not differ from those of non-breeding females (t-test for paired samples: $t=-2.128, d f=7, p=0.071$ ) or males (t-test for paired samples: $t=-0.903, d f=20, p=0.377)$. In general, wolves were less active and mobile during the cold season. Activity and movement were highest during the period of breeding and raising of young (April - October) (Fig. 4). 

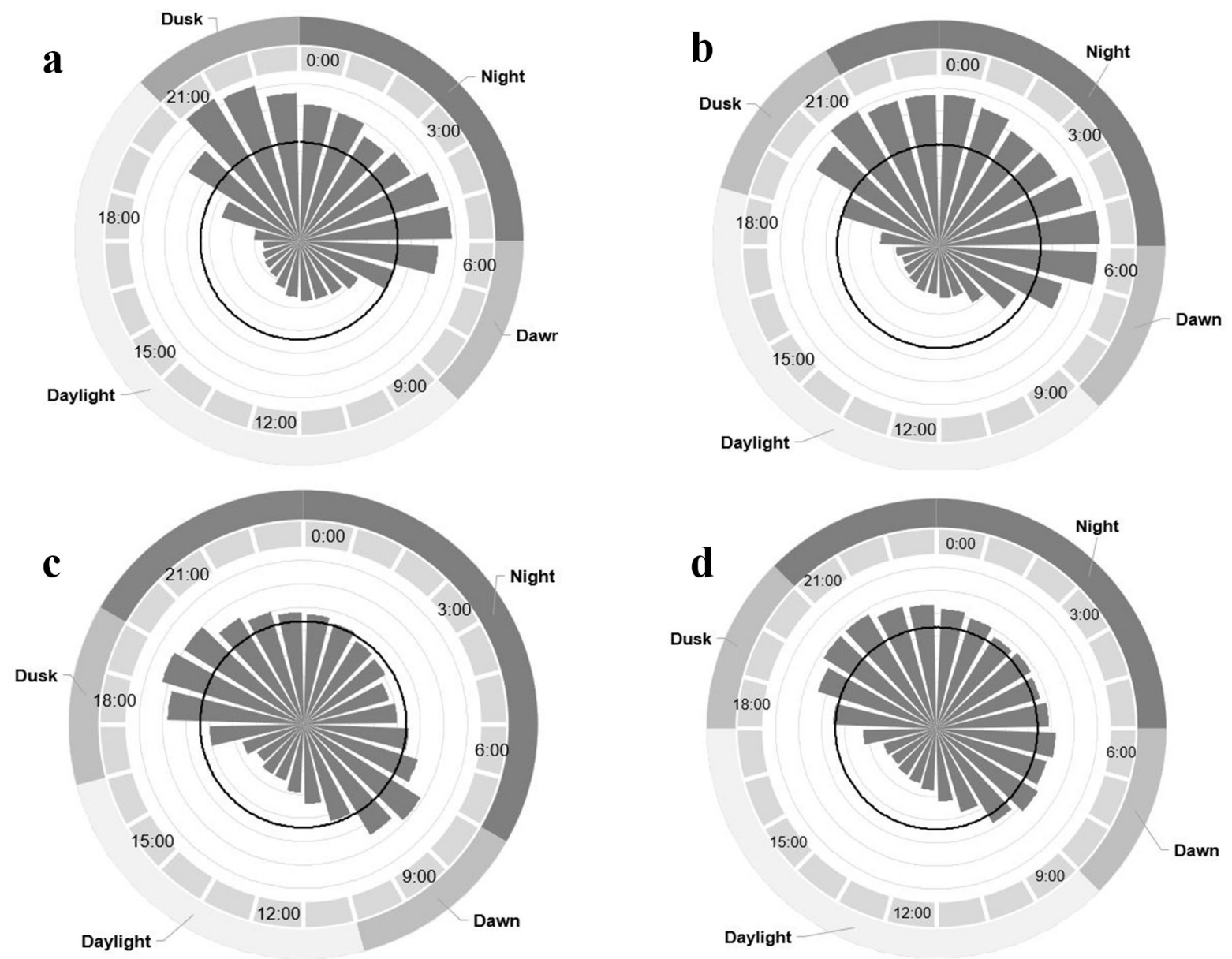

\begin{tabular}{|c|c|c|c|c|c|c|c|c|c|c|}
\hline Variable & $\mathbf{X}$ & & SE & & $\mathbf{X}$ & & SE & & $\mathbf{X}$ & \\
\hline \multicolumn{11}{|c|}{ Entire tracking period } \\
\hline & \multicolumn{2}{|c|}{ Whole day $(24 \mathrm{~h})$} & Dayligl & & \multicolumn{2}{|c|}{ Dusk (3 h) } & \multicolumn{2}{|c|}{ Night $(9 \mathrm{~h})$} & \multicolumn{2}{|c|}{ Dawn $(3 \mathrm{~h})$} \\
\hline Activity index & 0.44 & 0.02 & 0.27 & 0.02 & 0.47 & 0.04 & 0.5 & 0.03 & 0.52 & 0.03 \\
\hline & 10.5 & 0.5 & 2.5 & 0.16 & 1.4 & 0.12 & 4.53 & 0.25 & 1.56 & 0.08 \\
\hline \multicolumn{11}{|c|}{ Breeding season (Aprile-June) } \\
\hline & \multicolumn{2}{|c|}{ Whole day $(24 \mathrm{~h})$} & \multicolumn{2}{|c|}{ Daylight $(12 \mathrm{~h})$} & \multicolumn{2}{|c|}{ Dusk (3 h) } & \multicolumn{2}{|c|}{ Night $(6 \mathrm{~h})$} & \multicolumn{2}{|c|}{ Dawn $(3 \mathrm{~h})$} \\
\hline Activity index & 0.43 & 0.03 & 0.24 & 0.02 & 0.67 & 0.05 & 0.61 & 0.04 & 0.59 & 0.05 \\
\hline & 10.37 & 0.7 & 2.9 & 0.29 & 2 & 0.14 & 3.66 & 0.24 & 1.77 & 0.15 \\
\hline \multicolumn{11}{|c|}{ Warm seasom (July-October) } \\
\hline & \multicolumn{2}{|c|}{ Whole day $(24 \mathrm{~h})$} & \multicolumn{2}{|c|}{ Daylight $(10 \mathrm{~h})$} & \multicolumn{2}{|c|}{ Dusk $(3 \mathrm{~h})$} & \multicolumn{2}{|c|}{ Night $(8 \mathrm{~h})$} & \multicolumn{2}{|c|}{ Dawn (3 h) } \\
\hline Activity index & 0.45 & 0.02 & 0.22 & 0.03 & 0.58 & 0.04 & 0.65 & 0.02 & 0.57 & 0.04 \\
\hline & 10.89 & 0.55 & 1.96 & 0.24 & 1.74 & 0.11 & 5.86 & 0.19 & 1.71 & 0.12 \\
\hline \multicolumn{11}{|c|}{ Cold season (November-March) } \\
\hline & \multicolumn{2}{|c|}{ Whole day $(24 \mathrm{~h})$} & \multicolumn{2}{|c|}{ Daylight $(6 \mathrm{~h})$} & \multicolumn{2}{|c|}{ Dusk (3 h) } & \multicolumn{2}{|c|}{ Night (12) } & \multicolumn{2}{|c|}{ Dawn $(3 \mathrm{~h})$} \\
\hline Activity index & 0.43 & 0.02 & 0.27 & 0.02 & 0.52 & 0.04 & 0.47 & 0.03 & 0.51 & 0.03 \\
\hline Time active (h) & 10.4 & 0.56 & 1.64 & 0.14 & 1.55 & 0.12 & 5.67 & 0.35 & 1.54 & 0.08 \\
\hline
\end{tabular}

Fig. 3. Daily patterns of the mean time active of 17 wolves for conditional seasons of the year. Designations: a - breeding season (April - June), b - warm season (July - October), c - cold season (November - March,), $d$ - year-round in the Dauria Ecoregion (Russia), 2015-2020. Designations of the rose-diagram plots: black line is a year-round mean activity index; grey area is a mean activity index per hour.

Table 3. Mean activity index of breeding female wolves in the Dauria Ecoregion, Russia, during three different seasons at night, dawn and dusk, 2015-2020

\begin{tabular}{|c|c|c|c|c|c|c|c|c|c|c|c|c|}
\hline \multirow{2}{*}{ Variable } & \multicolumn{3}{|c|}{ Breeding season } & \multicolumn{3}{|c|}{ Warm season } & \multicolumn{3}{|c|}{ Cold season } & \multicolumn{3}{|c|}{ Year-round } \\
\hline & Night & Dusk & Dawn & Night & Dusk & Dawn & Night & Dusk & Dawn & Night & Dusk & Dawn \\
\hline F1 & $0.33 \pm 0.01$ & $0.41 \pm 0.02$ & $0.31 \pm 0.0$ & $.63 \pm 0.0$ & $.62 \pm 0$ & $0.60 \pm 0.0$ & $.39 \pm 0.0$ & $.68 \pm 0$. & $.45 \pm 0.0$ & $.47 \pm 0.0$ & $46 \pm 0$. & $41 \pm 0.02$ \\
\hline $\mathrm{F} 4$ & $0.58 \pm 0.03$ & $0.71 \pm 0.04$ & $0.52 \pm 0.0$ & $.68 \pm 0.0$ & $.50 \pm 0$ & $0.47 \pm 0.0$ & $.51 \pm 0.0$ & $45 \pm 0$. & $.35 \pm 0.1$ & $.52 \pm 0.0$ & $49 \pm 0$. & $44 \pm 0.05$ \\
\hline
\end{tabular}


The overall activity index of wolves living/being in protected areas was not higher than among wolves living/being in the unprotected areas (t-test for paired samples: $t=-1.312, d . f .=19, P=0.205)$; as well as during the daylight in the hunting season (15 Septem- ber-28 February; t-test for paired samples: $t=0.072$, d. $f .=16, P=0.943)$. We examined activity patterns on sites with different human, road, and pastoral camps' density, but wolves did not significantly modify their activities and travel speed $(\mathrm{km} / \mathrm{h}$; Table 4$)$.
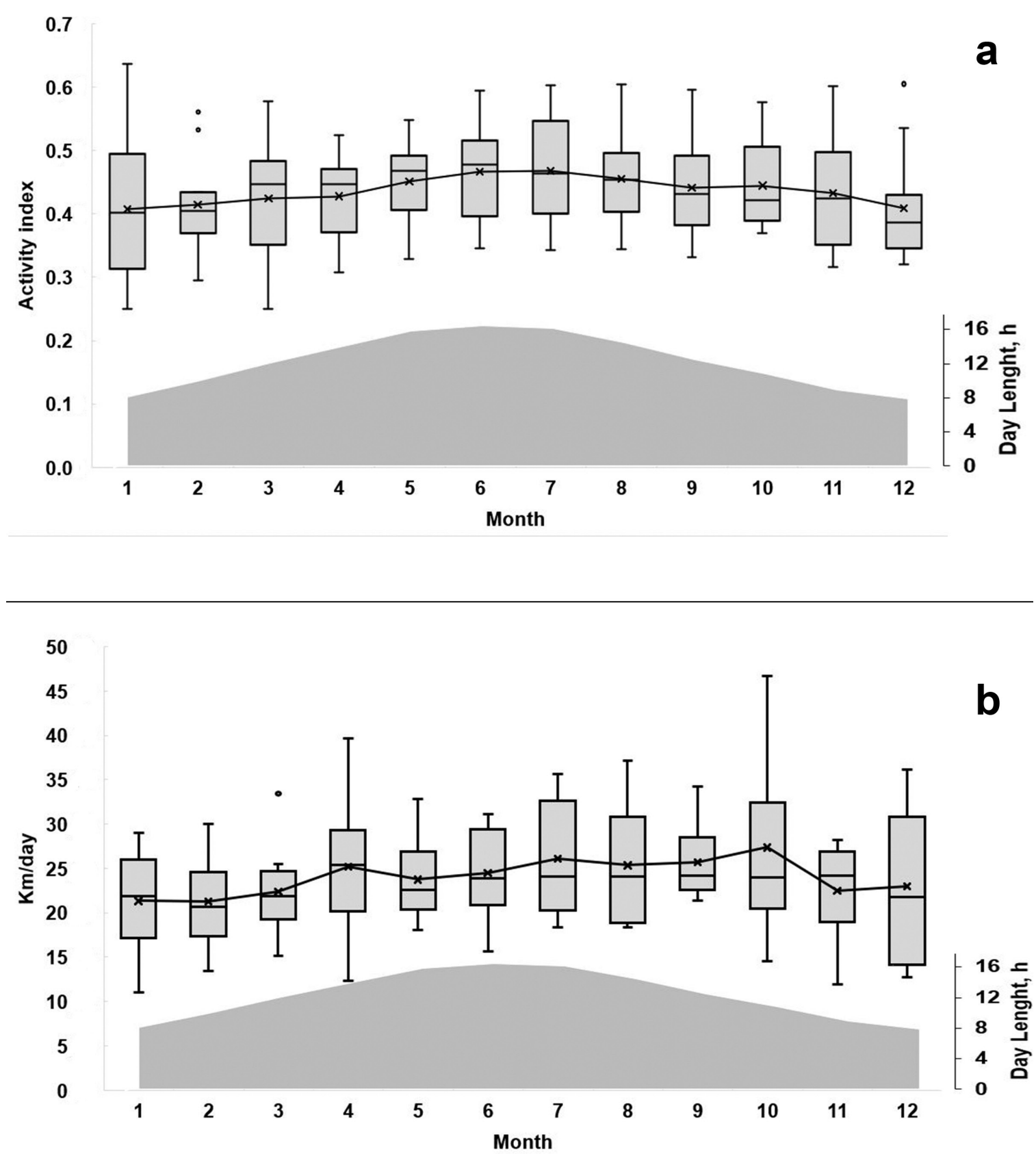

Fig. 4. Activity index (a) and travel speed km/d (b) of 17 collared wolves and day length in the Dauria Ecoregion, Russia, 2015-2020.

Table 4. Models tested for detecting anthropogenic factors influencing activity index and travel speed $(\mathrm{km} / \mathrm{h})$ of 15 collared wolves (17 home range territories) in the Dauria Ecoregion, Russia

\begin{tabular}{|c|c|c|}
\hline Linear model & Adjusted $\mathrm{R}^{2}$ & Model analysis \\
\hline$\overline{A I \sim H D+e}$ & 0.014 & $F_{l, l 5}=1.233, P=0.284$ \\
\hline$A I \sim P C D+e$ & -0.065 & $F_{l, l, 5}=0.025, P=0.876$ \\
\hline$A I \sim R D+e$ & -0.003 & $F_{l, l 5}=0.952, P=0.345$ \\
\hline$T S \sim H D+e$ & -0.028 & $F_{l, 15}=0.567, P=0.463$ \\
\hline$T S \sim P C D+e$ & 0.018 & $F_{l, I 5}=4.405, P=0.053$ \\
\hline$T S \sim R D+e$ & -0.061 & $F_{L / 5}=0.076, P=0.787$ \\
\hline
\end{tabular}

Note: AI - activity index, TS - traveled speed (km/d), HD - human density (mean \pm SD: $0.35 \pm 0.44$ inhabitants $\left./ \mathrm{km}^{2}\right), \mathrm{PCD}-$ density of pastoralist camps (mean \pm SD: $0.01 \pm 0.009 \mathrm{camps} / \mathrm{km}^{2}$ ), RD - road density (mean $\pm \mathrm{SD}: 0.28 \pm 0.12 \mathrm{~km} / \mathrm{km}^{2}$ ), e - residual. 
We tested the influence of wind speed, day mean temperature and precipitation intensity on daily patterns of wolf activity, but wolves increased time active by $0.1 \%\left(R^{2}=0.07, F_{1,2724}=20.359, p=0.000\right)$ and travel speed by $0.11 \mathrm{~km} / \mathrm{d}\left(R^{2}=0.016, F_{1,2724}=43.705\right.$, $p=0.000)$ only for each Celsius degree of increasing day mean temperature for year-round activity. This also corresponds to the day duration, when the longer day occurs with the higher temperature (Pearson's $r$ test: $r=0.915, p=0.000)$. Wolves did not reduce their mean activity on days with or without rain (ANOVA: $\left.F_{1.656}=0.112, p=0.738\right)$; as well, the activity (ANOVA: $F_{1.662}=1.248, p=0.264$ ) was not different on days with or without snowfall. We examined activity patterns on days with snowfall and right after snowfall, and wolves also did not significantly modify their activities (t-test for paired samples: $t=-1.245, d f=61, p=0.218$ ).

\section{Discussion}

We investigated the wolf circadian activity patterns with response to various ecological and anthropogenic factors in the low-human-density areas with vast open habitats in the Daurian steppe, Russia. In our study area, wolves had a nocturnal activity pattern with distinct peaks around dawn and dusk. Theuerkauf (2009) suggested that one of the reasons for a lower daytime activity might be that wolves need shelter from the sun when traveling, especially in open areas. Thus, the higher wolf activity at night during warm and breeding seasons (versus night activity during the cold season) in our study can be explained with high daily temperatures during the summer and spring months. On the other hand, being less active during the daytime and being more active during the night, wolves may also minimise encounters with humans (Vilà et al., 1995; Ciucci et al., 1997; Kusak et al., 2005; Chavez \& Gese, 2006; Karamanlidis et al., 2016).

Human disturbance in the form of raising livestock was a predominant land use in our study area. Vast areas of open habitat were also a dangerous environment for wolves to travel through the hunting period, including illegal poaching, outside Protected Areas. This is especially the case in winter and in places with a high density of steppe roads, as in the study area, wolf harvesting is primarily carried out using vehicles. Furthermore, we speculated the fact that in the steppe's open areas, surroundings are more visible, and it may influence wolves to be less active during the daytime, especially during the hunting season. But the highest mean daytime activity of wolves occurred in the cold season. In addition, wolves did not significantly modify their activities on days with snowfall and right after snowfall, when hunters usually track wolves on the day after a snowfall. Therefore, we assumed that, in contrast, it is easier for wolves to see humans and avoid encounters with them in such open areas. The exception may be on rare snowfall days without wind when wolves are easy to track. This argument is supported by our own and the Daursky Biosphere Reserve rangers' observations. When wolves see a human (or vehicle), if those are far away, they lie down either in tall grass, or in depression or behind a hill. If a human (or a vehicle) is nearby, wolves try to run away to a place where a vehicle cannot pass. For instance, it might be a place with boulders, bushes, ravines, or lake bottoms.

Since vast open habitats (including pastures or hay-harvesting areas) were extensively used by wolves, and as wolves' activity and movements were not correlated to human-related factors, and did not differ between Protected Areas and surrounding territories, it seems that human disturbance factors (human density, density of pastoral camps and road density) did not appear to have a major influence on wolves' daily patterns; they reduced their daytime activity because of other factors. Besides, we found no influence of livestock predation events on shaping high activities of wolves during the night or in the early morning (before 10:00 h), as wolf attacks were relatively rare and caused primarily by circumstances that increased a chance for depredation (for example, teaching young wolves, sick and weak prey, lack of oversight by shepherds, inadequate corrals) (Kirilyuk \& Ke, 2020).

In contrast to previous studies (Jedrzejewski et al., 2001; Theuerkauf et al., 2003a; Eggermann et al., 2009; Eriksen et al., 2011; Mancinelli, 2017), where wolves were primarily most active during the cold season, we also found seasonal changes of wolves' activity, with wolves being more active during warm (April - October) days. This was also proved by the correlation between wolves' activity and movements with day duration (temperature). We speculate that this result may be related to two different causes or the combination between them. So, at first, wolves may be more active during the warm period because of raising young ones. Secondly, wolves may tend to conserve energy being less active and mobile during cold days, which was probably also related to the mange (Sarcoptes scabiei) (Cross et al., 2016) pandemic among wolves in 2017-2019. However, after wolves' collaring, we did not visually observe tracked wolves and cannot prove this claim. 
We also found that wolves' social status affected their activity patterns. Thus, floaters were found to be more active than pack-member wolves, as well as during daylight hours. The growth of aggressiveness of dominant individuals may be the mechanism explaining the increased diurnality of floaters (Mancinelli, 2017). Floaters' temporal avoidance of pack members or other pack territories, by moving along the pack's periphery, especially during pre-dispersal forays (Kirilyuk et al., 2020), could be their adaptive strategy, as the subordinate status may make them particularly vulnerable to attack from conspecifics (Treves et al., 2009). In general, dispersers suffer a higher mortality than resident individuals (Messier, 1985; Blanco \& Cortés, 2007; Suvorov \& Kirienko, 2008), while the mortality can also be caused by other wolves (Mech et al., 1998; Cassidy et al., 2017). Besides floaters, resident wolves (pack members) also showed a higher mobility and a few times switched their movement patterns to diurnal, while conducting extraterritorial forays and crossing neighbouring pack territories. Merrill \& Mech (2003) reported similar results in their study. We infer that such behaviour also lets wolves avoid conflicts and mortality. Wolf pack territories are maintained through territorial surveillance, howling, scent marking and aggressive behaviour (Harrington \& Mech, 1979; Mech \& Boitani, 2003; Zub et al., 2003; Schlägel et al., 2017). Aggressive interactions may sometimes lead to the death of individual wolves, and these interactions are used as a measure of intra-specific strife within wolf populations (Cassidy et al., 2017; Mech \& Boitani, 2003). Aggressive interactions, especially increased during the mating season (Mech \& Boitani, 2003; Smith et al., 2015), which likely explains why most of the cases occurred in winter, when the studied wolves switched their movement patterns to diurnal.

In our study, two breeding females did not reduce their overall activity and movement during the period of reproduction. However, F1 was less active at night and dawn, probably indicating that other wolves may have provided her with food (Theuerkauf et al., 2003a; Tsunoda et al., 2008). In our study, breeding females did not spend much of their denning time, compared to previous studies (Ballard et al., 1991; Vilà et al., 1995; Jedrzejewski et al., 2001; Schmidt et al., 2008; Theuerkauf et al., 2003a,b; Mancinelli, 2017). We associate this with the fact that in such open areas, breeding females often keep at a distance from a den (up to $2 \mathrm{~km}$, depending on landscapes), visually monitoring the situation around it. We observed this behaviour seven times. This probably al- lows them to increase in safety of offspring and exclude the simultaneous death of offspring and other adult wolves at the same time when humans appear.

By referring to other environmental factors, we examined the influence of weather conditions and found that wind force and precipitation intensity did not affect daily patterns of wolf activity. To confirm our findings, we suggest using a collar equipped with a weather sensor in future studies on the correlation between wolves' activity patterns and weather conditions.

Our findings revealing bimodal patterns (activity peaks at dawn and dusk) were likely related to synchronisation by wolves of their activity and habitat selection with the activity patterns of their main prey (Theuerkauf et al., 2003a; Chavez \& Gese, 2006; Pagon et al., 2013). Furthermore, it is probably easier to hunt prey around dawn and dusk, as the vision of Canis is best adapted to crepuscular light (Kavanau \& Ramos, 1975; Roper \& Ryon, 2009). However, due to our study design and lack of accurate data on prey activity, we did not attempt to determine how much prey activity affected their daily activity patterns. On the other hand, the human influence may be indirect, if hunters of ungulates modify the activity patterns of the wolves' prey (Theuerkauf et al., 2003a). In our case, in the studied Protected Areas, the prey density is relatively high (Kirilyuk et al., 2019), and potential prey is completely protected. But neither Protected Areas nor the relatively high density of ungulates in Protected Areas affected the wolf's activity, comparing to unprotected areas. This may indicate that the number of ungulates in the territory adjacent to the studied Protected Areas was still sufficient, and did not significantly affect the behaviour of the predator. The ungulate hunting pressure was not high either. On the other hand, the strictly protected part of the Daursky State Nature Biosphere Reserve is extremely small and cannot indicate the completely natural wolf activity, independent of anthropogenic impact.

\section{Conclusions}

We conclude that daily activity patterns of wolves in our study area might be caused by the combination of several factors, while being as close to natural as possible. Rearing of young ones had a temporary influence on wolves' activity patterns. Social affiliation markedly modified the behaviour of wolves, especially during extraterritorial forays and dispersing. Human activity appeared to have no effect on the temporal patterns of wolf activity. Besides, we consider that daily activity patterns of wolves in our study area were likely shaped by their 
pattern of hunting prey. But this hypothesis requires additional research to validate it. In general, wolf activity and travel speed are highly variable even among conspecifics that reflects the plasticity of their behaviour and wide adaptation strategies.

\section{Acknowledgements}

We thank the rangers of the Daursky State Nature Biosphere Reserve for help in conducting this survey. Special thanks go to Eleanor Eugenia Pate (Fort Worth, TX, USA) for her careful revisions and correcting English. This research was carried out as a part of the Research and Management Program of the Daursky State Nature Biosphere Reserve (Russia) and within the framework of the $\mathrm{PhD}$ Program in Northeast Forestry University (China). The work was also carried out within the framework of the Program of Fundamental Research of the Russian Academy of Sciences, project №121032200126-6. Procedures of animal captures and collaring were approved by the scientific council of the Daursky State Nature Biosphere Reserve. This research did not receive any specific grant from funding agencies in the public, commercial, or nonprofit sectors.

\section{References}

Ballard W.B., Ayres L.A., Gardner C.L., Foster J.W. 1991. Den site activity patterns of gray wolves, Canis lupus in southcentral Alaska. Canadian Field-Naturalist 105: 497-504.

Blanco J., Cortés Y. 2007. Dispersal patterns, social structure and mortality of wolves living in agricultural habitats in Spain. Journal of Zoology 273(1): 114-124. DOI: 10.1111/j.1469-7998.2007.00305.x

Cassidy K.A., Mech L.D., MacNulty D.R., Stahler D.R., Smith D.W. 2017. Sexually dimorphic aggression indicates male gray wolves specialize in pack defense against conspecific groups. Behavioural Processes 136: 64-72. DOI: 10.1016/j.beproc.2017.01.011

Chapron G., Kaczensky P., Linnell J.D.C., Von Arx M., Huber D., Andrén H., López-Bao J.V., Adamec M., Álvares F., Anders O., Balečiauskas L., Balys V., Bedõ P., Bego F., Blanco J.C., Breitenmoser U., Brøseth H., Bufka L., Bunikyte R., Ciucci P., Dutsov A., Engleder T., Fuxjäger C., Groff C., Holmala K., Hoxha B., Iliopoulos Y., Ionescu O., Jeremić J., Jerina K. et al. 2014. Recovery of large carnivores in Europe's modern human-dominated landscapes. Science 346(6216): 1517 1519. DOI: $10.1126 /$ science. 1257553

Chavez A.S., Gese E.M. 2006. Landscape Use and Movements of Wolves in Relation to Livestock in a Wildland-Agriculture Matrix. Journal of Wildlife Management 70(4): 1079-1086. DOI: 10.2193/0022-541x(2006)70[1079:lua mow]2.0.co;2

Ciucci P., Boitani L., Francisci F., Andreoli G. 1997. Home range, activity and movements of a wolf pack in central Italy. Journal of Zoology 243(4): 803-819. DOI: 10.1111/ j.1469-7998.1997.tb01977.x

Cross P.C., Almberg E.S., Haase C.G., Hudson P.J., Maloney S.K., Metz M.C., Munn A.J., Nugent P., Putzeys O., Stahler D.R., Stewart A.C., Smith D.W. 2016. Energetic costs of mange in wolves estimated from infrared thermography. Ecology 97(8): 1938-1948. DOI: 10.1890/15-1346.1

Eggermann J., Gula R., Pirga B., Theuerkauf J., Tsunoda H., Brzezowska B., Rouys S., Radler S. 2009. Daily and seasonal variation in wolf activity in the Bieszczady Mountains, SE Poland. Mammalian Biology 74(2): 159-163. DOI: 10.1016/j.mambio.2008.05.010

Eriksen A., Wabakken P., Zimmermann B., Andreassen H.P., Arnemo J.M., Gundersen H., Liberg O., Linnell J., Milner J.M., Pedersen H.C., Sand H., Solberg E.J., Storaas T. 2011. Activity patterns of predator and prey: A simultaneous study of GPS-collared wolves and moose. Animal Behaviour 81(2): 423-431. DOI: 10.1016/j.anbehav.2010.11.011

Gipson P., Ballard W., Nowak R., Mech L. 2000. Accuracy and Precision of Estimating Age of Gray Wolves by Tooth Wear. Journal of Wildlife Management 64(3): 752-758. DOI: $10.2307 / 3802745$

Greenwood P.J. 1980. Mating systems, philopatry and dispersal in birds and mammals. Animal Behaviour 28(4): 1140 1162. DOI: $10.1016 / \mathrm{S} 0003-3472(80) 80103-5$

Harrington F.H., Mech L.D. 1979. Wolf Howling and Its Role in Territory Maintenance. Behaviour 68(3/4): 207-249.

Iliopoulos Y., Youlatos D., Sgardelis S. 2014. Wolf pack rendezvous site selection in Greece is mainly affected by anthropogenic landscape features. European Journal of Wildlife Research 60(1): 23-34. DOI: 10.1007/ s10344-013-0746-3

Jedrzejewski W., Schmidt K., Theuerkauf J., Jedrzejewska B., Okarma H. 2001. Daily movements and territory use by radio-collared wolves (Canis lupus) in Bialowieza Primeval Forest in Poland. Canadian Journal of Zoology 79: 1993-2004. DOI: 10.1139/z01-147

Kaartinen S., Antikainen H., Kojola I. 2015. Habitat Model for a Recolonizing Wolf (Canis lupus) Population in Finland. Annales Zoologici Fennici 52(1-2): 77-89. DOI: 10.5735/086.052.0207

Karamanlidis A., de Gabriel Hernando M., Georgiadis L., Kusak J. 2016. Activity, movement, home range and habitat use of an adult gray Wolf in a Mediterranean landscape of northern Greece. Mammalia 81(1): 95-99. DOI: 10.1515/mammalia-2015-0091

Karlsson J., Brøseth H., Sand H., Andrén H. 2007. Predicting occurrence of wolf territories in Scandinavia. Journal of Zoology 272(3): 276-283. DOI: 10.1111/j.14697998.2006.00267.x

Kavanau J.L., Ramos J. 1975. Influences of Light on Activity and Phasing of Carnivores. American Naturalist 109(968): 391-418.

Kirilyuk A., Ke R. 2020. Wolf depredation on livestock in Daursky State Nature Biosphere Reserve, Russia. Journal for Nature Conservation. 58: 125916. DOI: 10.1016/j.jnc.2020.125916

Kirilyuk A., Kirilyuk V. 2019. Human-wolves conflicts in the north-east of the Daurian Ecoregion. In: Transboundary Regions Under Global Change: Current Challenges and Development Trajectories. Gorno-Altaysk. P. 231-235.

Kirilyuk O., Kirilyuk V., Maksakovskiy N., Kobyakova S., Goroshko O., Tkachuk T., Butorin A., Namkhay A., Urt- 
nasan N., Tseveenmyadag N., Oyungerel B., Dashdorj K., Knapp K., Golde A. 2014. Landscapes of Dauria Potential Serial Transnational World Heritage Property (The Russian Federation and Mongolia). Moscow: ANNIE. 60 p. [In Russian]

Kirilyuk V.E., Kirilyuk A.V., Minaev A.N. 2019. Wolf's home range and movements in Daurian steppe. Nature Conservation Research 4(4): 91-105. DOI: 10.24189/ ncr.2019.068 [In Russian]

Kirilyuk A., Kirilyuk V.E., Ke R. 2020. Long-distance dispersal of wolves in the Dauria ecoregion. Mammal Research 65(4): 639-646. DOI: 10.1007/s13364-020-00515-w

Kochetkov V.V. 2007. Dynamics and structure of developing wolf population under anthropogenic pressure: Features and patterns. Biology Bulletin 34(2): 185-193. DOI: 10.1134/S1062359007020112

Kojola I., Aspi J., Hakala A., Heikkinen S., Ilmoni C., Ronkainen S. 2006. Dispersal in an Expanding Wolf Population in Finland. Journal of Mammalogy 87(2): 281-286. DOI: 10.1644/05-MAMM-A-061R2.1

Kojola I., Hallikainen V., Mikkola K., Gurarie E., Heikkinen S., Kaartinen S., Nikula A., Nivala V. 2016. Wolf visitations close to human residences in Finland: The role of age, residence density, and time of day. Biological Conservation 198: 9-14. DOI: 10.1016/j.biocon.2016.03.025

Kusak J., Skrbinšek A.M., Huber D. 2005. Home ranges, movements, and activity of wolves (Canis lupus) in the Dalmatian part of Dinarids, Croatia. European Journal of Wildlife Research 51(4): 254-262. DOI: 10.1007/s10344-005-0111-2

Mancinelli S. 2017. Being in the right place at the right time: wolf spatio-temporal niche in a human-modified environment. PhD Thesis. Rome: SAPIENZA Universita Di Roma. 143 p.

Mancinelli S., Boitani L., Ciucci P. 2018. Determinants of home range size and space use patterns in a protected wolf (Canis lupus) population in the central apennines, Italy. Canadian Journal of Zoology 96(8): 828-838. DOI: $10.1139 / \mathrm{cjz}-2017-0210$

Mancinelli S., Falco M., Boitani L., Ciucci P. 2019. Social, behavioural and temporal components of wolf (Canis lupus) responses to anthropogenic landscape features in the central Apennines, Italy. Journal of Zoology 309(2): 114-124. DOI: 10.1111/jzo. 12708

Mech L.D. 1999. Alpha status, dominance, and division of labor in wolf packs. Canadian Journal of Zoology 77(8): 1196-1203. DOI: 10.1139/z99-099

Mech L.D., Boitani L. 2003. Wolf Social Ecology. In: Wolves. Behavior, Ecology, and Conservation. Chicago \& London: University of Chicago Press. P. 1-34.

Mech L.D., Adams L.G., Meier T.J., Burch J.W., Dale B.W. 1998. The wolves of Denali. Minneapolis: University of Minnesota Press. 227 p.

Merrill S., Mech L. 2003. The Usefulness of GPS Telemetry to Study Wolf Circadian and Social Activity. Wildlife Society Bulletin 31(4): 947-960. DOI: 10.2307/3784439

Messier F. 1985. Social organization, spatial distribution, and population density of wolves in relation to moose density. Canadian Journal of Zoology 63(5): 1068-1077. DOI: $10.1139 / \mathrm{z} 85-160$
Messier F. 2011. Solitary living and extraterritorial movements of wolves in relation to social status and prey abundance. Canadian Journal of Zoology 63(2): 239245. DOI: $10.1139 / \mathrm{z} 85-037$

Musiani M., Okarma H., Jẹdrzejewski W. 1998. Speed and actual distances travelled by radiocollared wolves in Bialowieza Primeval Forest (Poland). Acta Theriologica 43(4): 409-416. DOI: 10.4098/AT.arch.98-51

Pagon N., Grignolio S., Pipia A., Bongi P., Bertolucci C., Apollonio M. 2013. Seasonal variation of activity patterns in roe deer in a temperate forested area. Chronobiology International 30(6): 772-785. DOI: 10.3109/07420528.2013.765887

R Core Team. 2020. R: A language and environment for statistical computing. Vienna, Austria: R Foundation for Statistical Computing. Available from https://www.R-project.org/

Roper T., Ryon J. 2009. Mutual synchronization of diurnal activity rhythms in groups of Red wolf/coyote hybrids. Journal of Zoology 182(2): 177-185. DOI: 10.1111/ j.1469-7998.1977.tb04154.x

Schlägel U.E., Merrill E.H., Lewis M.A. 2017. Territory surveillance and prey management: Wolves keep track of space and time. Ecology and Evolution 7(20): 8388 8405. DOI: $10.1002 /$ ece 3.3176

Schmidt K., Jędrzejewski W., Theuerkauf J., Kowalczyk R., Okarma H., Jędrzejewska B. 2008. Reproductive behaviour of wild-living wolves in Białowieża Primeval Forest (Poland). Journal of Ethology 26(1): 69-78. DOI: 10.1007/s10164-006-0031-y

Scott B.M.V., Shackleton D.M. 1982. A preliminary study of the social organization of the Vancouver Island Wolf: ( $\mathrm{Ca}$ nis lupus). In: Wolves of the world: perspectives of behavior, ecology, and conservation. New Jersey: William Andrew Publishing. P. 12-24.

Smith D.W., Metz M.C., Cassidy K.A., Stahler E.E., Mcintyre R.T., Lmberg E.S.A., Stahler D.R. 2015. Infanticide in wolves: Seasonality of mortalities and attacks at dens support evolution of territoriality. Journal of Mammalogy 96(6): 1174-1183. DOI: 10.1093/jmammal/gyv125

Suvorov A., Kirienko N. 2008. Features of self-regulation in wolf populations of Prienisei Siberia. Bulletin of KrasGAU 6: 105-111. [In Russian]

Theuerkauf J. 2009. What drives wolves: Fear or hunger? Humans, diet, climate and wolf activity patterns. Ethology 115(7): 649-657. DOI: 10.1111/j.14390310.2009.01653.x

Theuerkauf J., Jẹdrzejewski W., Schmidt K., Okarma H., Ruczyński I., Śniezko S., Gula R. 2003a. Daily patterns and duration of wolf activity in the Białowieża Forest, Poland. Journal of Mammalogy 84(1): 243-253. DOI: 10.1644/1545-1542(2003)084<0243:DPADOW>2.0.CO;2

Theuerkauf J., Rouys S., Jedrzejewski W. 2003b. Selection of den, rendezvous, and resting sites by wolves in the Bialowieza Forest, Poland. Canadian Journal of Zoology 81(1): 163-167. DOI: 10.1139/z02-190

Theuerkauf J., Gula R., Pirga B., Tsunoda H., Eggermann J., Brzezowska B., Rouys S., Radler S. 2007. Human impact on wolf activity in the Bieszczady Mountains, SE Poland. Annales Zoologici Fennici 44(3): 225-231. 
Treves A., Martin K., Wiedenhoeft J., Wydeven A. 2009. Dispersal of Gray Wolves in the Great Lakes Region. In: Recovery of Gray Wolves in the Great Lakes Region of the United States: An Endangered Species Success Story. New York: Springer. P. 191-204. DOI: 10.1007/978-0-387-85952-1_12

Tsunoda H., Gula R., Theuerkauf J., Rouys S., Radler S., Pirga B., Eggermann J., Brzezowska B. 2008. How does parental role influence the activity and movements of breeding wolves? Journal of Ethology 27(1): 185-189. DOI: $10.1007 / \mathrm{s} 10164-008-0106-\mathrm{z}$

Vilà C., Urios V., Castroviejo J. 1995. Observations on the daily activity patterns in the Iberian wolf BT. In: Ecology and Conservation of Wolves in a Changing World. Alberta: Canadian Circumpolar Institute. P. 335-340.

Walzer C., Kaczensky P., Ganbaatar O., Lengger J., Enkhsaikhan N., Lkhagvasuren D. 2006. Capture and Anaesthesia of Wild Mongolian Equids - the Przewalski's
Horse (Equus ferus przewalskii) and Khulan (E. hemionus). Mongolian Journal of Biological Sciences 4(1): 19-28. DOI: $10.22353 /$ mjbs.2006.04.02

White G., Garrot R.A. 1990. The Analysis of Wildlife RadioTracking Data. New York: Academic Press. 383 p. DOI: 10.1016/B978-0-08-092657-5.50008-2

Worton B.J. 1989. Kernel Methods for Estimating the Utilization Distribution in Home-Range Studies. Ecology 70(1): 164-168. DOI: 10.2307/1938423

Yachmennikova A.A., Poyarkov A.D. 2011. A new approach to study organization of wolves' activity (Canis lupus) in time sequences. Biology Bulletin 38(2): 156-164. DOI: 10.1134/S1062359011020154

Zub K., Theuerkauf J., Jȩdrzejewski W., Jedrzejewska B., Schmidt K., Kowalczyk R. 2003. Wolf Pack Territory Marking in the Bialowieza Primeval Forest (Poland). Behaviour 140(5): 635-648. DOI: $10.1163 / 156853903322149478$

\title{
ОСОБЕННОСТИ СУТОЧНОЙ АКТИВНОСТИ ВОЛКА В ОТКРЫТЫХ МЕСТООБИТАНИЯХ ДАУРСКОГО ЭКОРЕГИОНА, РОССИЯ
}

\author{
А. В. Кирилюк ${ }^{1,2, * \mathbb{D}, \text { В. Е. Кирилюк }}{ }^{1,3} \mathbb{D}$, А. Н. Минаев ${ }^{4}$ \\ ${ }^{1}$ Даурский государственный природный заповедник, Россия \\ ${ }^{2}$ Северо-Восточный Лесной Университет, Китай \\ *e-mail:akiriliuk@bk.ru \\ ${ }^{3}$ Институт природных ресурсов, экологии и криологии СО РАН, Россия \\ ${ }^{4}$ Институт проблем экологии и эволюичи РАН имени А.Н. Северияова, Россия
}

\begin{abstract}
Почти нет сведений об особенностях суточной активности Canis lupus (далее - волк), обитающего в открытых местообитаниях, мало населенных людьми степной зоны Даурии. Мы изучили влияние основных факторов беспокойства, связанных с деятельностью человека, погодными условиями, социальным, репродуктивным статусом и возрастом волка на суточную активность 17 особей, помеченных в Даурском заповеднике GPS-ошейниками с 2015 по 2020 гг. Передатчики фиксировали местоположение раз в час, а также статус «активен / не активен» каждые 10 мин (402750 фиксаций, в среднем - $23691 \pm 18534.5$ фиксаций). Удалось выявить, что в среднем за сутки волки активны 10.5 ч (44\% $\pm 0.02 S E)$ при средней скорости 1.21 км/ч ( $\pm 0.10 S E)$. Средняя продолжительность непрерывной активности составляла 7.36 ч $( \pm 1.49 S E)$, а непрерывного покоя - 10.07 ч $( \pm 4.2 S E)$. Обнаружена высокая корреляция между скоростью перемещения (км/ч) и индексом активности (r-критерий Пирсона: $r=0.876, p=0.000)$. Суточная дистанция перемещений значительно увеличивается, когда волки заходят на территории соседних стай. Самые высокие индекс активности характерны для расселяющихся волков. Мы не нашли достоверных различий в активности волков, живущих на территории ООПТ (включая охранную зону) и вне их. Установлено, что погодные условия (сила ветра, количество осадков и экстремальные погодные условия), деятельность человека (сезоны охоты и сенокоса, плотность дорог, плотность сельскохозяйственных стоянок) на активность достоверного влияния не оказывают. Значение имеет продолжительность светлого времени суток и связанная с ней среднесуточная температура. Так, чем выше температура, тем выше активность и подвижность волков. Изученные особи в целом были менее активны и подвижны в холодный период (ноябрь - март). У всех волков выявлен пик сумеречных перемещений и активности. Однако пятеро из них меняли модель активности на дневную восемь раз во время рейдов на территории чужих стай. Результаты работы позволяют сделать вывод, что закономерности суточной активности волков формируются комбинацией нескольких факторов. Однако нами не исследована зависимость активности волков от активности их основной добычи, что было выявлено исследованиями в других частях ареала.
\end{abstract}

Ключевые слова: аридные местообитания, Даурский заповедник, дистанция перемещения, индекс активности, размножение, расселение, человеческая деятельность 